\title{
Studies of the Pathogenesis of Angioimmunoblastic Lymphadenopathy
}

\author{
Masaaki Honda, Howard R. Smith, and Alfred D. Steinberg \\ Cellular Immunology Section, Arthritis and Rheumatism Branch, National Institute of Arthritis, Diabetes, \\ and Digestive and Kidney Diseases, National Institutes of Health, Bethesda, Maryland 20205
}

\begin{abstract}
We studied the immune functions of two patients with angioimmunoblastic lymphadenopathy (AILD) in an attempt to determine whether the $B$ cells were primarily hyperactive or, rather, if $\mathbf{T}$ cell abnormalities might underlie the $B$ cell hyperactivity observed in these patients. We found that the $B$ cells of the AILD patients did not proliferate spontaneously, nor were they induced to proliferate excessively by fresh normal $T$ cells. In contrast, AILD T cells induced both autologous and allogeneic $B$ cells to proliferate and to differentiate into Ig secreting cells. Spontaneous culture supernates of $T$ cells obtained from each patient induced substantial proliferation of $B$ cells (B cellactivating activity) as well as proliferation in a standard costimulatory assay (B cell growth factor activity). The culture supernate of a $T$ cell line, which was established from one patient, showed both activities. The $T$ cell line supernate also induced Ig production by staphylococcal A Cowan-activated B cells. None of these properties of AILD $T$ cells was found among 10 normal controls.

The addition of AILD T cells to autologous or allogeneic $B$ cells in the presence of pokeweed mitogen (PWM) led to marked suppression of both proliferation and Ig production. This was true even in the presence of fresh normal $T$ cells. Pretreatment studies showed that suppressor cells were induced by the interaction of AILD $T$ cells with PWM-activated B cells.

The present study suggests that the B cell hyperactivity observed in AILD patients might in part be due to excessive $T$ cell effects on $B$ cells. In addition, our results may help clarify the paradoxical impaired responsiveness to in vitro stimulation with PWM by active B cells from patients with autoimmune diseases.
\end{abstract}

\section{Introduction}

Angioimmunoblastic lymphadenopathy (AILD) ${ }^{1}$ is a disorder that has been described in the last $30 \mathrm{yr}$ (1), but which has

Address correspondence to Dr. Steinberg, Building 10, Room 9N-218, National Institutes of Health, Bethesda, MD 20205.

Received for publication 4 December 1984 and in revised form 1 March 1985.

1. Abbreviations used in this paper: AILD, angioimmunoblastic lymphadenopathy; anti- $\mu, \mathrm{F}\left(\mathrm{ab}^{\prime}\right)_{2}$ fragment of goat anti-human IgM antibody; BCDF, B cell differentiation factor(s); BCGF, B cell growth factor(s); $\left[{ }^{3} \mathrm{H}\right] \mathrm{TdR}$, tritiated thymidine; IL-1, IL-2, interleukins 1 and 2; MNC, peripheral blood mononuclear cells; MNC-CS, culture supernate obtained from MNC, PHA, phytohemagglutinin; PHA-CS, culture supernate obtained from PHA; PWM, pokeweed mitogen; SLE, systemic lupus erythematosus.

The Journal of Clinical Investigation, Inc.

Volume 76, July 1985, 332-340 only been accepted as a clinical and pathologic entity worldwide for the past decade (2-5). This disorder is characterized by a clinical picture of fever, chills, sweats, malaise, anorexia, rash, hepatosplenomegaly, and marked lymphadenopathy. Laboratory abnormalities usually include hypergammaglobulinemia and anemia, which is often Coombs positive. The diagnosis must be confirmed histologically. The lymph nodes show a pleomorphic infiltration that includes immunoblasts and immunocytes and can obliterate the normal lymph node architecture. An important diagnostic criterion is the marked arborization of small vessels in the lymph node. In addition, an amorphous acidophilic interstitial material is often prominently found. Despite the impressive clinical and histologic abnormalities, the adenopathy consists of polyclonally activated immunoblasts, often B cells, without obvious malignancy. Nevertheless, the typical patient has a life expectancy of $\sim 1$ yr. Most patients with AILD die of infection. A minority of patients go on to develop a frank lymphoreticular malignancy; the potential to develop such a malignancy may possibly be predicted on the basis of hyperdiploidy of lymphoid cells early in the course of the illness (6). Although the clinical features have led to the belief that AILD is a single illness, differences have been stressed in some reports (7), and it is possible that AILD represents a syndrome with more than one clinicopathologic syndrome and/or more than one etiology.

Although the clinical and pathologic features of patients with AILD are becoming better understood, there is considerable confusion regarding the cellular abnormalities that underlie this disorder (7-13). Most patients have an abnormal composition of their peripheral blood leukocytes. It has been suggested that suppressor $\mathrm{T}$ cell functions may be deficient in AILD, thereby leading to B cell hyperactivity (9). Autonomous B cell hyperactivity has been proposed by other investigators as the major problem in the disorder (7). However, patients with AILD may vary over time so that cellular functions may be different at different times; moreover, the exact mechanisms of B cell hyperactivity are not well defined by the previous studies. Because anti-erythrocyte autoantibodies are found in many patients (2), and there is an association with other autoimmune syndromes (14-16), understanding the immune basis of AILD might shed light upon other diseases as well. For these reasons, as well as the rapidly progressive nature of the disorder, we undertook a study of the cellular basis of disease in two patients with AILD. We were aided in our human studies by observations in two mouse strains, MRLlpr/lpr and C3H-gld/gld. These two strains also develop massive lymphadenopathy, hypergammaglobulinemia, and autoantibodies (17-20). Their $\mathrm{T}$ cells produce factors that can activate $B$ cells and drive them to proliferate and become immunoglobulin secreting cells (17). Therefore, our studies attempted to determine whether AILD B cells were spontaneously hyperactive or whether an excess of helper $T$ cell function might underlie the syndrome. The studies suggest that AILD $\mathrm{T}$ cells activate B cells and drive them to proliferate and to produce 
immunoglobulin. We also conducted experiments to explain the paradoxical impaired responsiveness to in vitro stimulation with pokeweed mitogen by $B$ cells which are active in vivo (21-25).

\section{Methods}

Patients and source of lymphocytes and plasma. Patients with AILD and systemic lupus erythematosus (SLE) were hospitalized at the Clinical Center, National Institutes of Health, Bethesda, Maryland; the patients agreed in writing to being studied according to an approved informed consent form. The patients with AILD had classic lymph node histology and clinical symptomatology (2-5). They were studied early in the course of their illness. Lymphocytes and plasma from the patients with AILD used in in vitro studies were obtained before any treatment. Plasma of patients with AILD used in this study had been fresh frozen and had not been previously thawed. All plasma were centrifuged at $13,000 \mathrm{~g}$ for $15 \mathrm{~min}$ at $4^{\circ} \mathrm{C}$ to remove aggregated materials before use.

Isolation of $T$ cells, B cells, and monocytes. Peripheral blood mononuclear cells (MNC) were isolated by Ficoll-Hypaque gradient centrifugation. T cells, and non-T cells were separated from MNC by rosetting with neuraminidase-treated sheep erythrocytes $(26,27)$. Doubly purified nonrosetting cells were twice depleted of monocytes by removal of cells adhering to plastic petri dishes. The percentage of $T$ cell contamination in the nonadherent, nonrosetting B cell population was $<1 \%$. For some experiments, B cells were further treated with OKT3 monoclonal antibody plus complement to obtain B cells greatly depleted of $\mathrm{T}$ cells. After this additional purification, $\mathrm{T}$ cell contamination in the $B$ cell enriched population was $<0.5 \%$. Monocyte contamination in the B cell-enriched population was $10-20 \%$ as determined by esterase staining.

Development of a $T$ cell line from an AILD patient. MNC, $2 \times 10^{6}$, were cultured in RPMI 1640 with $10 \%$ fetal calf serum, 5 $\times 10^{-5} \mathrm{M} 2$-mercaptoethanol, $1 \%$ L-glutamine, penicillin $(100 \mathrm{U} / \mathrm{ml})$, streptomycin $(100 \mu \mathrm{g} / \mathrm{ml})$, and $20 \mathrm{ng} / \mathrm{ml}$ phorbol myristate acetate for 1 wk. After harvesting the MNC culture supernate (MNC-CS), these precultured MNC were separated into a $\mathrm{T}$ cell-enriched population by the E-rosette method. These separated $T$ cells were cultured with irradiated autologous non-T cells or an irradiated Epstein-Barr virustransformed B cell line for one week alternating with phytohemagglutinin (PHA) culture supernate (PHA-CS) for $1 \mathrm{wk}$. After $\sim 1 \mathrm{mo}$, a $\mathrm{T}$ cell line was established. To obtain the $T$ cell culture supernate, the separated T cells were washed well and then $1 \times 10^{6} / \mathrm{ml}$ of $\mathrm{T}$ cells were cultured in the same medium mentioned above for $1 \mathrm{wk}$, and the culture supernate was harvested for in vitro studies. $T$ cell lines from patients with SLE were also established by the same method.

Flow cytometry. $10^{6}$ cells $/ 0.1 \mathrm{ml}$ of sorter buffer (phosphatebuffered saline containing $0.05 \%$ bovine serum albumin and $0.1 \%$ sodium azide) were incubated with each monoclonal antibody for 30 min on ice, washed twice with sorter buffer, and then stained with the $F\left(a b^{\prime}\right)_{2}$ fragment of fluoresceinated goat anti-mouse IgG for $30 \mathrm{~min}$ on ice. After an additional three washes, these cells were analyzed on a fluorescence-activated cell sorter (FACS IV, Becton-Dickinson \& Co., Mountain View, CA). For some experiments, fluorescein-conjugated monoclonal antibodies were used.

Monoclonal antibodies. OKT 3, OKT 4, OKT 8, OKT 9, and OKT 10 monoclonal antibodies were purchased from Ortho Diagnostic Systems Inc., Raritan, NJ. Leu-10 and anti-HLA-DR were purchased from the Becton-Dickinson Monoclonal Center, Inc., Mountain View, CA. Anti-Tac was kindly provided by Dr. T. A. Waldmann, National Cancer Institute.

Study of culture supernate, plasma, or $T$ cell line of $A I L D$ patients on $B$ cell activation, proliferation, and differentiation. To assay B cell activating activity, highly purified $B$ cells, $10^{5}$, suspended in RPMI 1640 containing $10 \%$ fetal calf serum, $5 \times 10^{-5} \mathrm{M}$ 2-mercaptoethanol, $1 \% \mathrm{~L}$-glutamine, penicillin $(100 \mathrm{U} / \mathrm{ml})$, and streptomycin $(100 \mu \mathrm{g} / \mathrm{ml})$, were cultured in 96-well flat-bottomed microtiter plates (Costar, Data Packing, Cambridge, MA) with culture supernate or plasma, or irradiated $T$ cell line $\left(10^{5}\right)$ in the presence or absence of the $F\left(a b^{2}\right)_{2}$ fragment of goat antihuman IgM antibody (anti- $\mu$ ) (final concentration: $25 \mu \mathrm{g} / \mathrm{ml}$; Cappel Laboratories, Inc., Cochranville, PA) in a $95 \%$ air $/ 5 \% \mathrm{CO}_{2}$ humid atmosphere at $37^{\circ} \mathrm{C}$ for $72 \mathrm{~h}$, and pulsed with $1 \mu \mathrm{Ci}$ of $\left[{ }^{3} \mathrm{H}\right]$ thymidine (New England Nuclear, Boston, MA). For a B cell growth factor (BCGF) standard, we used a PHA culture supernate obtained from Electronucleonics, Inc., Silver Spring, MD. This PHA culture supernate (PHA-CS) did not contain PHA or immune interferon and was used as a BCGF source after absorbing it with concanavalin A-activated $\mathrm{T}$ cells to remove irrelevant factors capable of binding to activated $\mathrm{T}$ cells. Incorporation of $\left[{ }^{3} \mathrm{H}\right]$ thymidine was measured in a liquid scintillation counter. For some experiments, highly purified B cells $\left(10^{5}\right)$ were cultured with irradiated $(2,000 \mathrm{rad})$ fresh $T$ cells or an irradiated (3,000 rads) $\mathrm{T}$ cell line $\left(10^{5} \mathrm{~T}\right.$ cells) in the presence of pokeweed mitogen (PWM; 1:100 dilution; Gibco Laboratories, Grand Island, NY). In other experiments, irradiated fresh $T$ cells or a $T$ cell line $\left(10^{5} \mathrm{~T}\right.$ cells), or culture supernate were added to the culture consisting of highly purified B cells $\left(10^{5}\right)$ plus anti- $\mu(25 \mu \mathrm{g} / \mathrm{ml})$ and BCGF to study whether or not the $T$ cell line or culture supernate of AILD patients has additive or synergistic effects on $B$ cell proliferation.

The ability of a $\mathrm{T}$ cell line to induce Ig synthesis was examined. Briefly, $2 \times 10^{5} \mathrm{~B}$ cells were cultured with various numbers of irradiated (3,000 rad) $\mathrm{T}$ cells in the presence or absence of PWM (1:100 dilution) for $10 \mathrm{~d}$. To study the ability of a culture supernate to induce B cells to produce immunoglobulin, B cells, $2 \times 10^{6} / \mathrm{ml}$, were cultured with formalin-fixed staphylococcal A cells (final concentration, $0.001 \%$; Bethesda Research Laboratories, Inc., Gaithersburg, MD) for $3 \mathrm{~d}$. After washing, preactivated B cells, $2 \times 10^{5}$, were cultured with various amounts of culture supernate for an additional $5 \mathrm{~d}$. Culture supernates were harvested, and polyclonal Ig synthesis was measured by enzymelinked as immunosorbent assay described previously (19). For a B cell differentiation factor (BCDF) standard, PHA and immune interferon free PHA-CS was used. For some experiments, fresh B cells or a $T$ cell line $\left(10^{6}\right.$ cells) were precultured with PWM (1:100 dilution) for $30 \mathrm{~h}$. After washing thoroughly, cell mixing studies were carried out to determine the effect of $\mathrm{T}$ cells on Ig synthesis of B cells.

Interleukin-1 (IL-1) assay. The IL-1 assay was performed as described (28). Briefly, a single cell suspension of thymocytes (1.5 $\times 10^{7} / \mathrm{ml}$ ) from $\mathrm{C} 3 \mathrm{H} / \mathrm{HeJ}$ mice was prepared and suspended in RPMI 1640 with $5 \%$ fetal calf serum, $2.5 \times 10^{-5} \mathrm{M} 2$-mercaptoethanol 2 $\mathrm{mM}$ L-glutamine, and antibiotics. Thymocytes were cultured for $72 \mathrm{~h}$ at $1.5 \times 10^{6}$ cells/well in 96-well flat-bottomed plates in the presence of $1 \mu \mathrm{g} / \mathrm{ml}$ PHA (Wellcome Reagents Division, Research Triangle Park, NC) and serial dilutions of the test samples. Cultures were pulsed for the final $5 \mathrm{~h}$ with $0.5 \mu \mathrm{Ci}\left[{ }^{3} \mathrm{H}\right]$ thymidine.

Interleukin-2 (IL-2) assay. Plasma or supernates from NMC, T cells, or a $\mathbf{T}$ cell line were tested for their ability to maintain the growth of the IL-2-dependent HT-2 T cell clone (29). Briefly, triplicate wells containing $4 \times 10^{3}$ HT-2 cells were suspended in $100 \mu$ of medium and incubated with an equal volume of various concentrations of the test samples for $24 \mathrm{~h}$. The cultures were then pulsed with $1 \mu \mathrm{Ci}$ of $\left[{ }^{3} \mathrm{H}\right]$ thymidine $5 \mathrm{~h}$ before harvest.

Production of a monoclonal antibody (33.2.1) against human $B$ cells. A monoclonal antibody against human B cells (33.2.1) was established as described previously (30), and characterized in our previous paper (31). Briefly, this antibody recognizes an Ia-like determinant on non-T cells (a 28,000/32,000-mol wt heterodimer) and interferes with $B$ cell activation more effectively than conventional anti-HLA-DR and anti-HLA-DS/DC reagents.

\section{Results}

Studies of AILD T cells. Because AILD is characterized by marked numbers of immunoblasts and production of large amounts of antibody, we wished to study whether the $T$ cells 
might be important in the induction of $B$ cell activation, proliferation, and/or differentiation. Either the AILD $T$ cells are important in such induction or the AILD B cells are spontaneously hyperactive or non-T cell stimuli (e.g., exogenous agents) might be responsible for the B cell hyperactivity.

We obtained fresh MNC from two patients with AILD and studied their ability to induce $B$ cell proliferation and differentiation. We found that spontaneous culture supernate of $T$ cells obtained from each patient induced substantial proliferation of $\mathrm{B}$ cells (B cell activation activity) as well as proliferation in a standard costimulatory assay (BCGF activity) (Table I). Neither of these properties of AILD T cells was found among 10 normal controls studied at the same time and in an identical manner. In addition, there was no detectable IL-1 or IL- 2 activity in the AILD T cell supernates. The whole mononuclear cell supernate (MNC-CS) did not have B cell activating or BCGF activities. In that this is the same population from which the $T$ cells were obtained for the $T$ cell supernate, we presume that either other cells are capable of inhibiting production of the factor(s), or, more likely, that they can absorb out or conceivably destroy the factors. In Table I we have listed the results of the assay for B cell activating factor

Table I. B Cell Activating Activity and

BCGF Activity of Spontaneous Culture Supernate or Plasma of Patients with AILD*

\begin{tabular}{lllll}
\hline Plasma & $\begin{array}{l}\text { B cell } \\
\text { activating activity }\end{array}$ & BCGF & IL-1 & IL-2 \\
\hline AILD no. 1 & 0 & 0 & ND & ND \\
MNC-CS & 0 & 0 & 0 & 0 \\
T-CS & + & + & 0 & 0 \\
AILD no. 2 & 0 & 0 & ND & ND \\
MNC-CS & 0 & 0 & 0 & 0 \\
T-CS & + & + & 0 & 0 \\
TCL-CS & + & + & 0 & 0 \\
Normal $(n=10)$ & 0 & 0 & ND & ND \\
MNC-CS & 0 & 0 & 0 & 0 \\
T-CS & 0 & 0 & 0 & 0 \\
& & & & \\
\hline
\end{tabular}

MNC-CS, mononuclear cell culture supernate; ND, not determined; T-CS, T cell culture supernate; TCL-CS, T cell line culture supernate.

Criteria for positive B cell activating activity or BCGF activity.

(a) Criteria for positive B cell activating activity:

$$
\begin{aligned}
& \text { actual counts per minute - counts per minute } \\
& \text { Positive: }>5=\frac{\text { by B cell alone }}{\text { counts per minute by B cell alone }}
\end{aligned}
$$

Normal T-CS is <3; PHA-CS absorbed by Con A-T cells is $<5$. (b) Criteria for positive BCGF activity:

$$
\text { Positive: }>3=\frac{\begin{array}{l}
\text { actual counts per minute }- \text { counts per minute } \\
\text { by B cells stimulated with anti- } \mu
\end{array}}{\text { counts per minute by B cells stimulated with anti- } \mu} \text {. }
$$

Activity of B cell activating factor(s) and BCGF was examined by using at least two different normal individuals as a source of $B$ cells. * Each activity was assayed by the methods described in Methods. Experiments were repeated three times with similar results. The proliferation induced by the AILD T-CS was significantly greater than that induced by normal T-CS, $P<0.0001$. (assayed by addition of supernate to B cells without anti- $\mu$ ) as separate from the assay for BCGF (assayed on B cells plus anti- $\mu$, the standard co-stimulatory assay). Whether or not these are different factors remains to be determined. Of interest, the plasma of the patients did not contain measurable activity. (This, however, may be a false negative result due to any of several possibilities including binding to or inhibition by serum proteins).

Patients with AILD are often quite ill and require vigorous therapy. We did not want to depend on fresh $\mathrm{T}$ cells from our patients, whom we knew would receive therapies that could alter their cellular functions. To study systematically the properties of the AILD T cells and to obtain enough supernate to do many studies, we tried to establish a $\mathrm{T}$ cell line from both patients. We were successful with one. The $\mathrm{T}$ cell line was $100 \%$ OKT $3^{+}$OKT $4^{+}$, and also expressed activated cell markers: OKT 9 (transferin receptor) 27\%, OKT 10 (activated $\mathrm{T}$ cell marker) 39\%, Leu-10 (HLA-DS/DC/MB) 10\%, HLADR $28 \%$, and Tac (IL-2 receptor) $29 \%$.

Ability of the AILD $T$ cell line to induce proliferation of autologous and allogeneic $B$ cells. The AILD T cell line was compared with fresh normal $T$ cells and $T$ cell lines from two patients with SLE for the ability to induce $B$ cells to proliferate. All $T$ cells were irradiated before culture so that their contribution to the proliferation would be eliminated (this was confirmed; data not shown). We found that the fresh normal $\mathrm{T}$ cells failed to induce dramatic proliferation of $\mathrm{B}$ cells. This was true whether allogeneic or autologous B cells were used (Table II). Moreover, the AILD B cells did not proliferate spontaneously (data not shown), nor were they induced to proliferate by fresh normal $T$ cells (Table II). In contrast, the AILD $T$ cell line induced both allogeneic and autologous $B$ cells to proliferate dramatically (Table II). The SLE T cell lines also induced significant proliferation; however, this was not as great as that induced by the AILD T cell lines.

Ability of the AILD T cell line to induce B cells to produce immunoglobulin. We next asked whether, in addition to inducing proliferation of B cells, the AILD T cell line could induce Ig secretion. The data in Table III show that the AILD $\mathrm{T}$ cell line can, in fact, induce Ig production by unstimulated

Table II. Ability of the AILD T Cell Line, but Not

SLE T Cell Lines or Fresh T Cells, to Induce

Proliferation of Autologous or Allogeneic B Cells*

\begin{tabular}{llrrr}
\hline Irradiated T cells & B cells & Expt. 1 & Expt. 2 & \multicolumn{1}{c}{ Expt. 3 } \\
\hline & & $\Delta c p m \ddagger$ & $\Delta c p m \ddagger$ & $\Delta c p m \ddagger$ \\
Fresh & + autologous & 68 & 119 & 364 \\
Fresh & + AILD & 101 & 115 & 98 \\
AILD line & + autologous & ND & 9,008 & 12,148 \\
AILD line & + allogeneic & 8,681 & 12,477 & 48,640 \\
SLE line no. 1 & + autologous & 1,320 & 1,115 & ND \\
SLE line no. 1 & + allogeneic & 1,854 & 2,520 & 5,528 \\
SLE line no. 2 & + autologous & 613 & 519 & ND \\
SLE line no. 2 & + allogeneic & 1,126 & 1,420 & 3,841
\end{tabular}

* B cells $\left(10^{5}\right)$ were cultured with irradiated T cells $\left(10^{5}\right)$ for $3 \mathrm{~d}$. $\left[{ }^{3} \mathrm{H}\right] \mathrm{TdR}$ was added for the last $16 \mathrm{~h}$ of culture.

‡ Results were expressed as $\Delta \mathrm{cpm}$ (mean counts per minute by $\mathrm{B}$ cells plus irradiated $T$ cells - mean counts per minute by $B$ cells alone). Standard errors of the means were $<15 \%$ of the means. 
Table III. Ability of the AILD T Cell Line to Induce Autologous or Allogeneic B Cells to Produce Immunoglobulin*

\begin{tabular}{|c|c|c|c|c|}
\hline \multirow[b]{2}{*}{ Cell combination $\ddagger$} & \multicolumn{4}{|c|}{ Ig production§ } \\
\hline & Expt. 1‡ & Expt. $2 \ddagger$ & Expt. $3 \ddagger$ & Expt. 4‡ \\
\hline & $n g / m l$ & $n g / m l$ & $n g / m l$ & $n g / m l$ \\
\hline B & 8 & 8 & 13 & 10 \\
\hline B + PWM & 4 & 5 & 25 & 10 \\
\hline$B+$ Fresh autologous $T$ & 8 & 8 & 10 & 22 \\
\hline \multicolumn{5}{|l|}{ B + Fresh autologous $T$} \\
\hline + PWM & 551 & 604 & 6,935 & 6,472 \\
\hline$B+$ AILD $T$ cell line & 604 & 653 & 317 & 224 \\
\hline
\end{tabular}

* B cells $\left(2 \times 10^{5}\right)$ and irradiated T cells $\left(2 \times 10^{5}\right)$ were cultured for $10 \mathrm{~d}$ with or without PWM and the supernates were harvested and analyzed for Ig production by the enzyme-linked immunosorbent assay.

¥ For exps. 1 and 2, all cells were obtained from the AILD patient. For exps. 3 and 4, fresh $T$ and $B$ cells were obtained from a single normal donor.

$\S$ Total Ig (IgM + IgG + IgA) was measured. Standard errors were $<20 \%$ of the means.

B cells. The Ig production induced was as great as that induced by the combination of fresh T cells plus PWM in the autologous assay (Table III, exps. 1 and 2). When B cells were obtained from normal donors, the combination of fresh $T$ cells plus PWM induced much more Ig production than that induced by the AILD $\mathrm{T}$ cell line, but the AILD $\mathrm{T}$ cell line was still able to induce normal B cells to produce Ig (Table III, exps. 3 and 4).

Additional studies with the $\mathrm{T}$ cell line were carried out with regard to both proliferation and differentiation (these are presented later); however, we next wished to ask whether a soluble factor or factors from AILD $T$ cells or the $T$ cell line might be responsible for the activation and differentiation of B cells. As a result, we obtained culture supernates from the AILD $T$ cell line and performed the following studies.

Ability of the supernate from the AILD $T$ cell line to activate $B$ cells to proliferate. B cells from normal donors were stimulated with one of the following: anti- $\mu, \mathrm{BCGF}$, or the AILD supernate. Anti- $\mu$ or BCGF separately induced modest proliferation with an increase in tritiated thymidine $\left(\left[{ }^{3} \mathrm{H}\right] \mathrm{TdR}\right)$ incorporation of about three- to fourfold (Table IV). The greatest degree of proliferation was induced by the supernate of the AILD T cell line ( $\sim 20$-fold) (Table IV).

The addition of anti- $\mu$ to the cultures containing B cells plus the AILD $\mathrm{T}$ cell line supernate led to an additional increase of $\sim 1.5-2$-fold in proliferation (Table IV). The addition of the AILD supernate to the combination of anti- $\mu$ + BCGF led to another increase in $\left[{ }^{3} \mathrm{H}\right] \mathrm{TdR}$ incorporation (Table IV). This result suggested that the AILD supernate had a factor or factors that could stimulate a population of B cells to proliferate. Because the population of $B$ cells used was not depleted of B cells partially activated in vivo, it is possible that the proliferation induced by anti- $\mu$ alone or by BCGF alone represented addition to a signal already received in vivo before the cell separation and culture

A dose-response curve for the AILD T cell line supernate was performed in three different experiments. With increasing
Table IV. Effects of Culture Supernate of T Cell Line Obtained from AILD Patient on Activation of $B$ Cells to Proliferate*

\begin{tabular}{lcc}
\hline B cells cultured with & Experiment 1 & Experiment 2 \\
\hline & mean cpm $\ddagger$ & mean cpm $\ddagger$ \\
0 & 322 & 851 \\
Anti- $\mu$ & 1,234 & 2,225 \\
BCGF & 1,561 & 2,588 \\
Culture supernate of AILD T cell line & 6,633 & 15,346 \\
Anti- $\mu$ + BCGF & 5,450 & 38,219 \\
Anti- $\mu$ + culture supernate & 8,750 & 36,540 \\
Anti- $\mu$ + BCGF + culture supernate & 10,000 & 75,373 \\
\hline
\end{tabular}

* Highly purified B cells $\left(10^{5}\right)$ were cultured with anti- $\mu(25 \mu \mathrm{g} / \mathrm{ml})$, BCGF, culture supernate, or the combination of them for $3 \mathrm{~d}$. $\left[{ }^{3} \mathrm{H}\right] \mathrm{TdR}$ was added for the last $16 \mathrm{~h}$ of culture. $\dagger$ Results were expressed as mean counts per minute of triplicate cultures. Standard errors of the means were $<15 \%$ of the means.

amounts of supernate, there was increasing proliferation of allogeneic normal B cells (data not shown). The magnitude of the increase reached 50 times control proliferation. In contrast, the ability of the AILD $T$ cell supernate to augment the proliferation of a stimulated (by $25 \mu \mathrm{g} / \mathrm{ml}$ anti- $\mu$ ) population of B cells was marginal (less than twofold).

Ability of the AILD T cell line supernate to induce immunoglobulin production: Normal B cells were activated with formalin-fixed Staphylococcal A Cowan I (Sac) organisms for $3 \mathrm{~d}$. The B cells were washed and then either PHA culture supernate or the AILD $\mathrm{T}$ cell line supernate was added and the cells were cultured for an additional $5 \mathrm{~d}$. The AILD T cell culture supernate, like PHA-CS, also was able to induce Ig production, but not quite to the same magnitude (Table V). We conclude from this experiment that the AILD supernate had BCDF activity as well as the prior demonstrated BCGF activity. During these experiments we found that unactivated B cells were not induced to produce Ig by PHA-CS. Finally, unactivated B cells were not induced to produce Ig by $25 \mu \mathrm{g} /$ ml anti- $\mu$ or the AILD T cell supernate. This last result may not be a true reflection of the capacity of the AILD supernate,

Table V. Effects of Culture Supernate of the AILD T Cell Line on Ig Production by Fresh B Cells or Sac-activated B Cells*

\begin{tabular}{lll}
\hline B cells $\left(2 \times 10^{5}\right)$ & Source of BCDF & Ig production \\
\hline & & $n g / m l$ \\
Fresh B & PHA-CS 25\% & $<1$ \\
Fresh B & AILD-CS 25\% & $<1$ \\
Fresh B & Anti- $\mu 25 \mu \mathrm{g} / \mathrm{ml}$ & 2 \\
Sac-activated B & 0 & 1 \\
Sac-activated B & PHA-CS 25\% & 830 \\
Sac-activated B & AILD-CS 25\% & $295 \ddagger$
\end{tabular}

* Fresh B cells or Sac-activated B cells $\left(2 \times 10^{5}\right)$ were cultured with PHA-CS or culture supernate obtained from the AILD T cell line, or with anti- $\mu$. The supernates were harvested as described in Methods, and analyzed for immunoglobulin production. Standard errors were $<20 \%$ of the means. This experiment was repeated twice. ¥ Significantly greater than with fresh $B$ cells, $P<0.001$, but signifcantly less than PHA-CS with Sac-activated B cells, $P<0.05$. 
but rather our inability to sequentially provide the proper factors in the proper concentrations from the AILD supernate.

Effect of the AILD T cell line on B cell proliferation in the presence of $P W M$. A series of experiments was initially set up to determine whether there might be an additive or synergistic effect of AILD $T$ cell stimulation on B cells plus PWM stimulation. In these experiments, the AILD $\mathrm{T}$ cells were compared with fresh $T$ cells autologous to the normal B cells under study. The fresh irradiated $\mathrm{T}$ cells failed to stimulate $\mathrm{B}$ cell proliferation very much. In contrast, the AILD T cell line was a very effective stimulus for B cell proliferation (Table VI). Whereas the fresh $T$ cells caused only a twofold increase or less, the AILD T cell line caused a 19-30-fold increase. However, the combination of fresh $\mathrm{T}$ cells plus PWM caused as good proliferation as did the AILD $T$ cells. Thus, the AILD $T$ cells provided an extremely strong proliferative signal. When PWM and the AILD T cell line were combined, the result was not a further increase, but rather, a decrease of $60 \%$ (Table VI). We then asked whether this was a result of suprastimulation. No evidence for this could be found in that further addition of anti- $\mu$ and/or PHA-CS to the culture of the AILD T cell line plus B cells (without PWM) led to even more proliferation (data not shown). Thus, there appeared to be something special about the combination of stimulation with PWM plus the AILD T cell line which led to suppression of B cell proliferation relative to that observed with the AILD $T$ cell line alone. We pursued this observation in the hope that it might shed some light upon the previously reported defect in the SLE MNC response to PWM as well as on the AILD T cells.

This suppression in association with PWM was further studied in a mixing experiment in which both the AILD T cell line and fresh $T$ cells were added to cultures of B cells, and total Ig was assayed (Fig. 1). The fresh T cells plus PWM led to Ig production as did the AILD $T$ cell line without PWM. However, the AILD T cell line plus PWM, with or without fresh $T$ cells, led to marked suppression. This result suggested that PWM might be inducing the AILD T cell line

Table VI. Although the AILD T Cell Line Has Marked Stimulatory Effects on B Cells, in the Presence of PWM Suppression Is Observed*

\begin{tabular}{llllc}
\hline Regulatory T cells $\ddagger$ & PWM & Experiment 1 & Experiment 2 & Experiment 3 \\
\hline & & mean cpm§ & mean cpm $\S$ & mean cpm \\
Fresh T cells & 0 & 584 & 963 & 565 \\
AILD T cell line & 0 & 9,197 & 14,967 & 16,387 \\
Fresh T cells & + & ND & 13,686 & 9,424 \\
AILD T cell line & + & ND & $5,692^{\prime \prime}$ & $5,180^{\prime \prime}$ \\
\hline
\end{tabular}

Proliferation of unstimulated B cells was: experiment 1, $516 \mathrm{cpm}$; experiment 2, $456 \mathrm{cpm}$; experiment 3, $469 \mathrm{cpm}$.

* Highly purified B cells $\left(10^{5}\right)$ were cultured with irradiated regulatory T cells $\left(10^{5}\right)$, with or without PWM (1:100 dilution).

$¥$ Fresh $T$ cells $\left(10^{5}\right)$, and B cells $\left(10^{5}\right)$ were obtained from the same normal donor. Fresh $\mathrm{T}$ cells and the $\mathrm{T}$ cell line were irradiated with 2,000 and $3,000 \mathrm{rad}$, respectively.

$\S$ Results were expressed as mean counts per minute of triplicate cultures. Standard errors of the means were $<15 \%$. This experiment was repeated three times with similar results.

"Significant decrease, $P<0.01$, compared to both AILD T cell line

+ PWM or fresh T cells + PWM

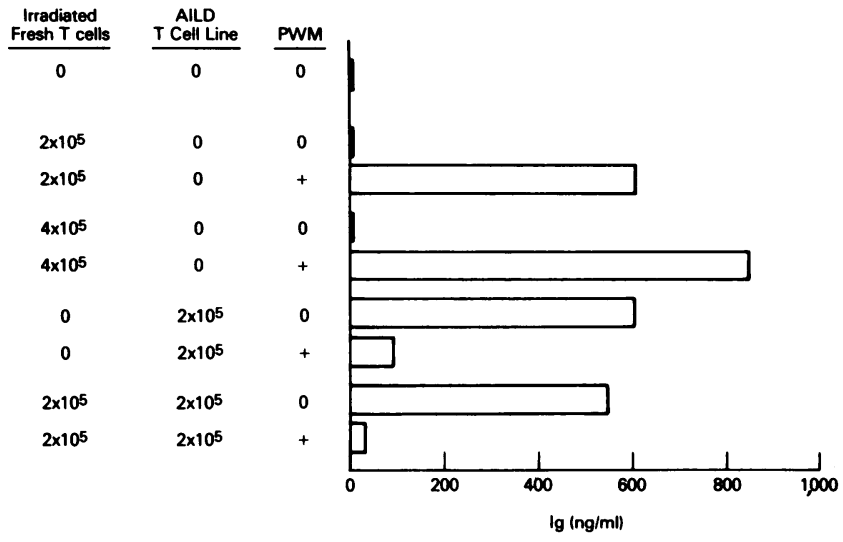

Figure 1. Effects of $\mathrm{T}$ cell line on polyclonal Ig synthesis. Fresh B cells $\left(2 \times 10^{5}\right)$ were cultured for $10 \mathrm{~d}$ with irradiated fresh $\mathrm{T}$ cells and/or the irradiated $T$ cell line in the presence or absence of PWM. The supernates were harvested and analyzed for immunoglobulin $(\operatorname{IgG}+\operatorname{IgM}+$ IgA) production. Standard errors of the means were $<20 \%$ of the means.

to suppress B cell Ig production, a suppression which could not be overcome by fresh $\mathrm{T}$ cells.

Suppression in the presence of PWM maps to the $B$ cell. To determine whether the PWM effect was on B cells or on the AILD $T$ cell line, $B$ cells and $T$ cells were separately preactivated by PWM. Preactivated $T$ cells were effective helpers for fresh B cells in the absence of PWM (Table VII, line 3). In contrast, preactivation of the $B$ cells prevented induction of Ig production by the AILD T cells (Table VII, line 8). This was true even when fresh $T$ cells were added. These results suggest that the AILD T cell line fails to stimulate preactivated B cells to secrete Ig, perhaps because the PWM signal in some way preempts the AILD T cell line signal. In addition, however, the AILD T cells suppressed the stimulatory capacity of fresh $T$ cells on preactivated B cells (Table VII, lines 7 and 9).

Finally, we examined whether during culture in the presence of PWM cytotoxic T cells against $B$ cells might be induced. For this purpose fresh B cells were cultured with the AILD T cell line in the presence or absence of PWM for $3 \mathrm{~d}$, then the viability of the B cells was studied. The B cells' viability with PWM and without PWM was similar. Thus the suppression by the AILD $T$ cell line observed in the presence of PWM appears not to be due to the induction of cytotoxic $T$ cells by PWM.

Effect of a monoclonal antibody that inhibits early events in $B$ cell activation. We have recently developed a monoclonal antibody which recognizes a new Ia-like determinant on $B$ cells (31). We have taken advantage of that antibody to test whether or not it might interfere with the ability of AILD T cells to activate $B$ cells, and thereby provide information regarding the activation of B cells by the AILD T cells. This study, shown in Table VIII, demonstrates that the antibody inhibited the proliferation of B cells in response to stimulation by the irradiated AILD T cells alone, in the presence of anti$\mu$, or in the presence of anti- $\mu$ plus BCGF. Although the inhibition was significant and substantial, it was not complete; moreover, there was little inhibition of the response of B cells to PWM + AILD T cells. In that the AILD T cells might have more than one effect on B cells, the supernate of the AILD T 
Table VII. Effect of PWM Preactivation of B Cells or AILD T Cells on Induction of Suppression

\begin{tabular}{llllc}
\hline & $\begin{array}{l}\text { Fresh } \\
\text { irradiated } \\
\text { B cells* }\end{array}$ & $\begin{array}{l}\text { Irradiated AILD } \\
\text { T cells* }\end{array}$ & PWM & Ig \\
\hline & & & & $n g / m l$ \\
Fresh & 0 & + & 0 & 450 \\
Fresh & 0 & + & + & $21 \ddagger$ \\
Fresh & 0 & PWM-preactivated & 0 & $304 \S$ \\
Fresh & 0 & PWM-preactivated & + & $25 \ddagger$ \\
PWM-activated & 0 & 0 & + & 3 \\
PWM-activated & + & 0 & 0 & 44 \\
PWM-activated & + & 0 & + & 657 \\
PWM-activated & 0 & + & 0 & 211 \\
PWM-activated & + & + & + & $36 \pi$ \\
& & & &
\end{tabular}

A number of controls not shown were as follows: fresh B cells alone $(<1 \mathrm{ng} / \mathrm{ml})$ or with PWM ( $<1)$; PWM-activated B cells alone (12);

PWM-activated B cells + AILD T cells + PWM (2); PWM-activated B cells + fresh T cells + AILD T cell line without PWM (16).

* Fresh B cells or PWM-preactivated B cells $\left(2 \times 10^{5}\right)$ were cultured with fresh irradiated T cells $\left(2 \times 10^{5}\right)$ or cells $\left(4 \times 10^{5}\right)$ from the AILD T cell line which were either preactivated with PWM or not and then irradiated. Cultures were with or without PWM for $10 \mathrm{~d}$ after which supernatants were harvested and analyzed for Ig production. Fresh B and T cells were from the same patient. Standard errors were $<20 \%$ of the means. This experiment was repeated twice with similar results.

$¥$ Significant suppression compared with cultures without PWM, $P<0.01$.

$\S$ Not significantly different from the result with nonpreactivated AILD T cells.

"Significantly less than the same culture containing fresh B cells, $P<0.01$.

I Significantly less than the same culture without AILD T cell line $(657 \mathrm{ng} / \mathrm{ml}), P<0.01$.

cell line was also studied (Table IX). In this study, the antibody 33.2.1 was able to completely overcome the stimulatory effects of the AILD $\mathrm{T}$ cell supernate. Control monoclonal antibodies had no effect.

\section{Discussion}

In this study, we found that the $\mathrm{T}$ cells of two patients with AILD and a $T$ cell line from one produce a factor or factors that activate autologous and allogeneic B cells and induce them to proliferate and secrete immunoglobulin. Whereas the AILD $T$ cells had abnormally increased inducer and helper activity for B cells, the AILD B cells did not manifest excessive responsiveness to $T$ cell signals nor were they spontaneously hyperactive. Thus, AILD patients examined in our study appeared to suffer from excessive $\mathrm{T}$ cell effects on B cells. A very similar mechanism for $B$ cell hyperactivity has been described recently for Kawasaki disease (32). In addition, our studies are reminiscent of those of Clement et al. (33), which demonstrated that mitogen activated $\mathrm{T}$ cells could induce proliferation of small, resting B cells. These results suggest the possibility that an endogenous mitogen might be activating $T$ cells in AILD and that the activated T cells, in turn, drive the B cells.

The ability of the AILD T cell supernates to induce B cell proliferation was assessed in two assay systems. The first measured $B$ cell activating function in that B cell proliferation was induced without addition of anti- $\mu$ or other B cell mitogens. The second assay was a standard co-stimulatory assay; highly purified B cells were cultured with the AILD or control T cell supernates in the presence of a suboptimal dose of anti- $\mu$. In these assays, $T$ cells were carefully removed from $B$ cell populations, a depletion that was confirmed both by cell sorter analysis and failure to respond to $T$ cell mitogens. However, because the $B$ cell population may not have been depleted of partially activated B cells, it is possible that the proliferation induced by anti- $\mu$ alone or by BCGF alone represented addition to a signal already received in vivo before cell separation. Moreover, we do not know in this study whether the two assays measuring B cell activation or co-stimulation are measuring the same or different factors, nor whether any of the activities involve multiple factors. We do know that the culture supernates do not contain measurable amounts of IL-1 or IL2; therefore, there was not a mere excessive production of all cytokines. Further study will be required for a full analysis of the factor or factors produced by the AILD T cells.

Previous studies have demonstrated spontaneous Ig production by MNC from AILD patients (8). Our findings are consistent with those reports in that AILD T cells plus AILD $B$ cells led to proliferation and Ig production $(7,10,11)$. However, in a previous study, AILD T plus AILD B plus PWM did not lead to proliferation (7) or to Ig production (10); unfortunately, those studies did not examine AILD T plus AILD B without PWM as we have. As a result, they may

Table VIII. Monoclonal Antibody (33.2.1) Inhibits B Cell Activation and Proliferation by the AILD T Cell Line*

\begin{tabular}{|c|c|c|c|c|}
\hline $\begin{array}{l}\text { Regulatory } \mathrm{T} \text { cells and/or } \\
\text { monoclonal antibody }\end{array}$ & B & $\mathbf{B}+\mathbf{P W M}$ & B + anti- $\mu$ & $B+$ anti- $\mu+$ BCGF \\
\hline & mean cpm $\ddagger$ & mean cpm $\ddagger$ & mean cpm $\ddagger$ & mean cpm‡ \\
\hline 0 & 469 & 623 & 507 & 9,978 \\
\hline Normal T cells & 565 & 9,424 & 936 & 14,984 \\
\hline $\mathrm{T}$ cell line & 16,387 & 5,180 & 33,088 & 50,725 \\
\hline $\mathrm{T}$ cell line + anti-DNA & 15,942 & 4,873 & 28,341 & 52,386 \\
\hline $\mathrm{T}$ cell line +33.2 .1 & $6,190[-62.0] \S$ & $4,480[-13.5] \S$ & $7,968[-75.9] \S$ & $23,204[-54.3] \S$ \\
\hline
\end{tabular}

* Highly purified B cells $\left(10^{5}\right)$ were cultured with one of the following or with a combination of them in the presence or absence of monoclonal antibody (33.2.1; $5 \mu \mathrm{g} / \mathrm{ml})$ or a control anti-DNA monoclonal antibody, $5 \mu \mathrm{g} / \mathrm{ml}$; PWM (1:100 dilution); anti- $\mu$ (25 $\mu \mathrm{g} / \mathrm{ml}) ; \mathrm{BCGF}$ (20\% vol/ vol); irradiated regulatory $\mathrm{T}$ cells $\left(10^{5}\right)$. Cultures were incubated for $3 \mathrm{~d} .\left[{ }^{3} \mathrm{H}\right] \mathrm{TdR}$ was added the last $16 \mathrm{~h}$ of culture. $\ddagger$ Standard errors were $<15 \% . \S[$ ] indicate \% suppression by monoclonal antibody. 
Table IX. Monoclonal Antibody (33.2.1) Inhibits B Cell Activation and Proliferation by the AILD T Cell Line Culture Supernate*

\begin{tabular}{|c|c|c|c|}
\hline $\begin{array}{l}\text { Culture supernate and/or } \\
\text { monoclonal antibody }\end{array}$ & B & $B+$ anti- $\mu$ & B + anti- $\mu$ + BCGF \\
\hline & mean cpm§ & mean cpm§ & mean cpm§ \\
\hline 0 & 257 & 2,225 & 23,864 \\
\hline AILD-CS & $7,673^{\prime \prime}$ & $25,549^{\prime \prime}$ & $37,687 \pi$ \\
\hline AILD-CS + 33.2.1 & $616[-92.0]^{11 *}$ & $2,325[-90.9]^{1 * * *}$ & $1,740[-95.4]^{\pi * *}$ \\
\hline
\end{tabular}

\begin{abstract}
* Cultures were performed as in Table 8 except that the culture supernate obtained from the AILD T cell line (AILD-CS) was used instead of the $T$ cells themselves. $¥$ A control anti-DNA monoclonal antibody did not suppress (data not shown). § Results were expressed as mean CPM of triplicate cultures. Standard errors of the means were $<15 \%$. An additional two experiments were performed and similar results were obtained. "Final concentration of culture supernate is $40 \%$. I Final concentration of culture supernate is $20 \%$. ** [ ] indicate \% suppression by monoclonal antibody.
\end{abstract}

have come to an incomplete conclusion based upon their finding of proliferation when AILD B cells were cultured with normal $T$ cells plus PWM. This result led to the conclusion that the AILD B cells were hyperactive. Our studies of the effects of PWM clarify the issue. In the presence of PWM, the AILD T cells led to marked suppression of Ig production. This is consistent with the findings of the incomplete studies cited above $(7,10,11)$. Moreover, such suppression was observed even in the presence of normal $T$ cells. Preactivation experiments implicated PWM-activated B cells in the induction of the suppression. This last result confirms previous reports of activated $B$ cells inducing suppression $(34,35)$.

In the present study, we used the AILD $\mathrm{T}$ cells, their supernates, and a $\mathrm{T}$ cell line established from one of the patients. The $T$ cell line was used in an attempt to carry out studies despite treatment of the patients. Although all of the cells in the $\mathrm{T}$ cell line were OKT $4^{+}$, we recognize that the line might have been heterogeneous. The PWM suppression studies suggest that the $\mathrm{T}$ cell line contained, in addition to helper cells, cells that participated in suppression. Alternatively, a single OKT $4^{+}$cell might have been able, under different conditions, to provide either helper or suppressor functions. Previous studies have demonstrated the ability of OKT $4^{+}$ cells to suppress as well as serve as inducers and helpers (36, 37). Moreover, we have recently cloned the AILD T cell line and have been able to separate a clone which is able to mediate helper functions but not suppressor functions. Thus, we believe that the different functions observed with the AILD T cell line might well derive from the functional heterogeneity within the line. Although the line does not mirror the $\mathrm{T}$ cell population in vivo, we believe that the $\mathrm{T}$ cell line represents cells which are critical to the AILD disease process.

The PWM suppression study may shed some light on previous studies of patients with SLE. Such patients manifest B cell hyperactivity in vivo and yet often have very poor responses to stimulation with PWM in vitro (21-25). It is possible that PWM induces suppression in those circumstances similar to the way that it induced suppression with the AILD cells.

Other studies of immune abnormalities in patients with AILD have implicated Epstein-Barr virus (38), impaired suppressor $\mathrm{T}$ cell function (9), and autonomous B cell hyperactivity (7). Moreover, occasional patients with AILD have been found to manifest impaired Ig production (10). Two explanations are possible for such diversity. The first is that patients may have different immune abnormalities at different stages of their disease. It is clear that some patients have hypergammaglobulinemia at one stage and either a severe infection or a lymphoreticular malignancy at another. Whereas excessive $T$ cell driven B cell function might occur at the first stage, impaired immune function might be caused by or result in the latter complications. In fact, excessive monocyte inhibition of B cell function has been implicated in the late hypogammaglobulinemia (10). Our patients have been studied relatively early in the course of their illness; we believe that the present observations may account for the B lymphoblasts and hypergammaglobulinemia. Just as autoimmune MRL-lpr/lpr mice eventually fail to respond well to immune stimulation after the lymphoproliferative process is well underway (39), so AILD patients may fail to respond to exogenous immune stimulation and thereby be susceptible to exogenous infections.

A second explanation for different findings in different patients with AILD is that the syndrome may have different causes. Previous authors have stressed differences among patients with AILD $(2-4,6,40-42)$. Thus, one group could be an extreme example of autoimmune lymphoproliferation and another group of AILD patients an early form of a lymphoid malignancy. However, it is not always easy to distinguish those two possibilities as many years of study of autoimmunelymphoproliferative mice indicate. Those mice often, but not invariably, carry retroviruses (43). The recent discovery of human retrovirus diseases (44-50) certainly raises the possibility that retroviruses may play a role in AILD. Just as infectious mononucleosis and Burkitt's lymphoma differ in being benign and malignant lymphoproliferation resulting from EpsteinBarr infection, so AILD may represent benign or malignant lymphoproliferation resulting from infection with one or more viruses. Inasmuch as studies of patients with Epstein-Barr infections have been quite informative, further study of AILD will undoubtedly shed light on various aspects of immune dysregulation in humans.

Our finding of $T$ cell driven B cell hyperactivity could conceivably be exploited therapeutically. Current therapy of AILD is marred by the desire to control the lymphoproliferation and yet not further predispose the patient to the infectious complications that claim the lives of the majority of AILD patients. It might be possible to interfere selectively with certain $T$ cell functions while leaving others intact. Alternatively, a direct effect on the $B$ cells might be attempted. In this regard, our in vitro inhibition of $T$ cell driven $B$ cell activation with an anti-Ia-like antibody suggests the possibility that one might be able to modulate early events in B cell activation so 
as to reduce but not eliminate B cell functions. Such a titration could, conceivably, allow the patient to experience a clinical benefit without the requirement for toxic drugs. Clearly much future research is necessary before such ideas leave the realm of speculation.

\section{Acknowledgments}

We thank Ms. Cheryl Yarboro and Ms. Carole Berkebile for performing leukaphereses, Mr. Pete Smith for assistance with flow cytometry, and Ms. Betty Irene Roupe for the skillful typing of this manuscript.

\section{References}

1. Forster, G., and S. Moeschlin. 1954. Extramedullares, leukemisches Plasmocytom mit Dysproteinämie underworbener hamolytischer Anämie. Schweiz. Med. Wochenschr. 84:1106-1110.

2. Frizzera, G., E. M. Moran, and H. Rappaport. 1974. Angioimmunoblastic lymphadenopathy with dysproteinaemia. Lancet. 1:10701073.

3. Frizzera, G., E. M. Moran, and H. Rappaport. 1975. Angioimmunoblastic lymphoadenopathy. Diagnosis and clinical course. Am. J. Med. 59:803-818.

4. Luhes, R. J., and B. H. Tindle. 1975. Immunoblastic lymphadenopathy. A hyperimmune entity resembling Hodgkins disease. $N$. Engl. J. Med. 292:1-8.

5. Cullen, M. H., A. G. Stansfeld, R. T. D. Oliver, T. A. Lister, and J. S. Malpas. 1979. Angioimmunoblastic lymphadenopathy: report of ten cases and review of literature. Q. J. Med. 48:151-176.

6. Kaneko, Y., R. A. Larson, D. Variakojis, J. M. Haren, and J. D. Rowley. 1982. Nonrandom chromosome abnormalities in angioimmunoblastic lymphadenopathy. Blood. 60:877-887.

7. Ershler, W. B., A. L. Moore, S. L. Burns, and B. H. Tindle. 1983. Immunoblastic lymphadenopathy: failure of, rather than lack of, immunoregulation. J. Med. (Westbury). 14:81-94.

8. Palutke, M., P. Khilanani, and R. Weise. 1976. Immunologic and electronmicroscopic characteristics of a case of immunoblastic lymphadenopathy. Am. J. Clin. Pathol. 65:929-941.

9. Bluming, A. Z., H. G. Cohen, and A. Saxon. 1979. Angioimmunoblastic lymphadenopathy with dysproteinemia. Am. J. Med. 67: $421-427$.

10. Rice, L., S. L. Abramson, A. H. Laughter, T. M. Wheeler, and J. J. Twomey. 1982. Angioimmunoblastic lymphadenopathy with hypogammaglobulinemaia. Am. J. Med. 72:998-1004.

11. Rubinstein, A., and L. G. Dauber. 1983. Lymphoma of cytotoxic/suppressor $T$ cell phenotype (T8) following angioimmunoblastic lymphadenopathy. Oncology. 40:195-199.

12. Ligler, F. S., M. Patel, D. Strayer, I. Brodsky, H. Bonner, and T. Juhanilinna. 1983. Extremely high levels of natural killer cells in angioimmunoblastic lymphadenopathy. J. Clin. Immunol. 3:375-381.

13. Stensvold, K., P. Brandtzaeg, S. Kvalog, M. Seip, and S. O. Lie. 1984. Immunoblastic lymphadenopathy with early onset in two boys: immunohistochemical study and indication of decreased proportion of circulating T-helper cells. Br. J. Haematol. 56:417-430.

14. Banhurst, A. D., and R. C. Williams. 1976. Cellular origins of autoantibody-A perplexing question. Am. J. Med. 61:303-307.

15. Popa, G., V. Nastase, and E. Hanganu. 1982. Angioimmunoblastic lymphadenopathy associated with systemic lupus erythematosus. Folia Haematol. (Leipz.). 109:430-434.

16. Starke, I. D., K. B. Elkon, C. L. Harmer, G. R. V. Hughes, and E. Wiltshaw. 1983. Pulmonary involvement in angioimmunoblastic lymphadenopathy following autoimmune disease. Respiration. 44:136142.

17. Prud'homme, G. J., C. L. Park, T. M. Fieser, R. Kofler, F. J. Dixon, and A. N. Theofilopoulos. 1983. Identification of a B cell differentiation factor(s) spontaneously produced by proliferating $\mathrm{T}$ cells in murine lupus strains of the lpr/lpr genotype. J. Exp. Med. 157:730742.

18. Roths, J. B., E. D. Murphy, and E. M. Eicher. 1984. A new mutation, gld that produces lymphoproliferation and autoimmunity in $\mathrm{C} 3 \mathrm{H} / \mathrm{HeJ}$ mice. J. Exp. Med. 159:1-20.

19. Steinberg, E. B., T. J. Santoro, T. M. Chused, P. A. Smathers, and A. D. Steinberg. 1983. Studies of congenic MRL-lpr/lpr $\cdot$ xid mice. J. Immunol. 131:2789-2795.

20. Mountz, J. D., A. D. Steinberg, D. M. Klinman, H. R. Smith and J. F. Mushinski. 1984. Autoimmunity and increased c-myb transcription. Science Wash. DC. 225:1087-1089.

21. Jasin, H. E., and M. Ziff. 1975. Immunoglobulin synthesis by peripheral blood cells in systemic lupus erythematosus. Arthritis Rheum. 18:219-228.

22. Ginsburg, W. W., F. D. Finkelman, and P. E. Lipsky. 1979. Circulating and pokeweed mitogen-induced immunoglobulin-secreting cells in systemic lupus erythematosus. Clin. Exp. Immunol. 35:76-88.

23. Blaese, R. M., J. Grayson, and A. D. Steinberg. 1980. Increased immunoglobulin-secreting cells in the blood of patients with active systemic lupus erythematosus. Am. J. Med. 69:345-350.

24. Budman, D. R., E. B. Merchant, A. D. Steinberg, B. Doft, M. E. Gershwin, E. Lizzio, and J. P. Reeves. 1977. Increased spontaneous activity of antibody-forming cells in the peripheral blood of patients with active SLE. Arthritis Rheum. 20:829-833.

25. Cohen, P. L., D. A. Lituin, and J. B. Winfield. 1982. Association between endogenously activated $T$ cells and immunoglobulin secreting B cells in patients with active systemic lupus erythematosus. Arthritis Rheum. 25:168-173.

26. Honda, M., T. Sakane, A. D. Steinberg, H. Kotani, T. Tsunematsu, K. Moriyama, and M. Fukase. 1982. Studies of immune functions of patients with systemic lupus erythematosus. Antibody to desialized, rather than intact, $T$ cells preferentially bind to and eliminate suppressor effector T cells. J. Clin. Invest. 69:940-949.

27. Honda, M., and A. D. Steinberg. 1984. Effect of prostaglandin $E_{2}$ on responses of $T$ cell subsets to mitogen and autologous non- $T$ cell stimulation. Clin. Immunol. Immunopathol. 33:111-121.

28. Rosenwasser, L. J., and C. A. Dinarello. 1981. Ability of human leukocytic pyrogen to enhance phytohemagglutinin-induced murine thymocyte proliferation. Cell. Immunol. 63:134-142.

29. Watson, J., S. Gillis, J. Marbrook, D. Mochizuki, and K. A. Smith. 1979. Biochemical and biological characterization of lymphocyte regulatory molecules. I. Purification of a class of murine lymphokines. J. Exp. Med. 150:849-855.

30. Kohler, G., and C. Milstein. 1975. Continuous cultures of fused cells secreting antibody of predefined specificity. Nature (Lond.). 256:495-497.

31. Honda, M., and A. D. Steinberg. 1985. Production and characterization of a unique monoclonal antibody against human B cells. Cell. Immunol. 93:105-123.

32. Leung, D. Y. M., E. T. Chu, N. Wood, S. Grady, R. Meade, and R. S. Geha. 1983. Immunoregulatory $T$ cell abnormalities in Mucocutaneous lymph node syndrome. J. Immunol. 130:2002-2004.

33. Clement, L. T., M. K. Dagg, and G. L. Gartland. 1984. Small, resting B cells can be induced to proliferate by direct signals from activated helper T cells. J. Immunol. 132:740-744.

34. Tosato, G., I. Magrath, I. Koski, N. Dooley, and R. M. Blaese. 1979. Activation of suppressor T-cells during Epstein-Barr virus induced infectious mononucleosis. N. Engl. J. Med. 301:1133-1137.

35. Calkins, C. E. 1982. Interactions between primed and unprimed cells in the regulation of in vitro antibody responses. I. Role of "plasma cells" as inducers of suppression. Eur. J. Immunol. 12:70-75.

36. Thomas, Y., L. Rogozinski, O. H. Irigoyen, S. M. Friedman, P. C. Kung, G. Goldstein, and L. Chess. 1981. Functional analysis of human $T$ cell subsets defined by monoclonal antibodies. IV. Induction of suppressor cells within the OKT $4^{+}$population. J. Exp. Med. 154: 459-467.

37. Kotani, H., S. Takada, Y. Ueda, Y. Muradawa, N. Suzuki, and T. Sakane. 1984. Activation of immune regulatory circuits among 
OKT $4^{+}$cells by autologous mixed lymphocytes reactions. Clin. Exp. Immunol. 56:390-398.

38. Robinson, J. E., N. Brown, W. Andiman, K. Halliday, V. Francke, M. F. Robert, M. Anderson-Anunet, D. Horstman, and G. Miller. 1980. Diffuse polyclonal B-cell lymphoma during primary infection with Epstein-Barr virus. N. Engl. J. Med. 303:1293.

39. Wilson, D. A., and H. Braley-Mullen. 1982. Immunoregulation in MRL-lpr/lpr mice. Evidence for decreased helper T cell and increased suppressor T cell function with age. Cell. Immunol. 74:72-80.

40. Hossfeld, D. K., K. Hoffken, C. G. Schmidt, and H. Diedrichs. 1976. Chromosome abnormalities in angioimmunoblastic lymphadenopathy. Lancet. 1:198.

41. Castroldi, G., G. Scapoli, G. D. Grunsovin, M. Gualandi, R. Spanedda, L. Cavazzini, and D. Anzanel. 1976. Chromosomal abnormalities in angioimmunoblastic lymphadenopathy. Ric. Clin. Lab. 6: 121-129.

42. Goh, K., and R. F. Bakemeier. 1970. Is angioimmunoblastic lymphadenopathy with dysproteinemia a malignant disease? J. Am. Women Assoc. 33:38.

43. Datta, S. D., F. L. Owen, J. E. Womack, and R. J. Riblet. 1982. Analysis of recombinant inbred lines derived from "autoimmune" (NZB) and "high leukemia" (C58) strains: independent multigenic systems control B cell hyperactivity, retrovirus expression, and autoimmunity. J. Immunol. 129:1539-1544.

44. Poiesz, B. J., F. W. Ruscetti, M. S. Reitz, U. S. Kalyanataman, and R. C. Gallo. 1981. Isolation of a new type C retrovirus (HTLV) in primary uncultured cells of a patient with Sezary T-cell leukemia. Nature (Lond.). 294:268-271.
45. Robert-Gurott, M., Y. Nakano, Y. Ito, A. Slishi, and R. C. Gallo. 1982. Natural antibodies to human retrovirus HTLV in a cluster of Japanese patients with adult $\mathrm{T}$ cell leukemia. Science (Wash. DC). 215:975-978.

46. Sarin, P. S., T. Aoki, A. Sibata, Y. Ohnishi, Y. Aoyagi, H. Miyakoshi, I. Emura, U. S. Kalyanaraman, P. C. Nowell, and R. C. Gallo. 1983. High incidence of human type-C retrovirus (HTLV) in family members of a HTLV-positive Japanese T-cell leukemia patient. Proc. Natl. Acad. Sci. USA 80:2370-2374.

47. Gelman, E. P., M. Popovic, D. Blayney, H. Masur, G. Sidhu, R. E. Stahl, and R. C. Gallo. 1983. Proviral DNA of a retrovirus, human T-cell leukemia virus, in two patients with AIDS. Science (Wash. DC). 220:862-865.

48. Gallo, R. C., P. S. Sarin, E. P. Gelmann, M. Robert-Guroff, E. Richardson, V. S. Kalyanaraman, D. Mann, G. Sidhu, R. E. Stahl, S. Zolla-Pazner, J. Leibovitch, and M. Popovic. 1983. Isolation of human T-cell leukemia virus in acquired immune deficiency syndrome (AIDS). Science (Wash. DC). 220:865-867.

49. Barre-Sinoussi, F., J. C. Chermann, F. Rey, M. T. Nugeyre, S. Chamaret, J. Gruest, C. Danguet, C. Axler-Blin, F. Vezinet-Brun, C. Rouzioux, W. Rozenbaum, and L. Montagnier. 1983. Isolation of a T-lymphotropic retrovirus from a patient at risk for acquired immune deficiency syndrome (AIDS). Science (Wash. DC). 220:868-871.

50. Blattner, W. A., V. S. Kalyanaraman, M. Robert-Gurott, T. Andrew-Lister, D. A. G. Galton, P. S. Sarin, M. H. Crawford, D. Catovsky, M. Greaves, and R. C. Gallo. 1982. The human type-C retrovirus, HTLV, in blacks from the Caribbean region, and relationship to adult T-cell leukemia/lymphoma. Int. J. Cancer. 30:257-264. 